\title{
Analisis Technology Acceptance Model (TAM) pada Sistem E-Learning Universitas Advent Indonesia
}

\author{
Tabita Indri Hasmarawati Siahaan dan Elmor Benedict Wagiu \\ Fakultas Teknologi Informasi, Universitas Advent Indonesia
}

\begin{abstract}
ABSTRAK
E-learning system merupakan salah satu elemen pendukung dalam kegiatan proses belajar mengajar, dimana proses tersebut dilakukan melalui media internet. Para pelajar maupun pengajar berinteraksi tanpa bertatap muka secara langsung. E-learning system yang digunakan pada Universitas Advent Indonesia adalah Moodle. Dengan adanya Moodle ini para mahasiswa dapat mengumpulkan tugas dan mengunduh materi perkuliahan yang diberikan oleh dosen. Sedangkan bagi dosen dapat mengunggah materi perkuliahan dan mengunduh tugas yang sudah dikumpulkan oleh para mahasiswa. Adapun tujuan dari penelitian ini adalah (1) untuk mengetahui apakah seluruh menu dalam Moodle telah digunakan secara optimal atau tidak, dan (2) untuk mengetahui bagaimana pengaruh persepsi manfaat dan kemudahan dalam penerimaan pengguna terhadap Moodle Universitas Advent Indonesia. Sedangkan hasil dari penelitian ini adalah (1) Penerimaan Moodle pada Fakultas Teknologi Informasi Universitas Advent Indonesia dinyatakan baik, (2) penggunaan keseluruhan menu dalam Moodle belum optimal, dan (3) persepsi manfaat dan kemudahan mempengaruhi penerimaan pengguna terhadap Moodle.
\end{abstract}

Kata-kata kunci: E-learning system, moodle, TAM, penerimaan, kuesioner.

\section{ANALYSIS OF TECHNOLOGY ACCEPTANCE MODEL (TAM) ON UNIVERSITAS ADVENT INDONESIA E-LEARNING SYSTEM}

\begin{abstract}
The e-learning system is one of the supporting elements in the teaching and learning process, where the process is carried out through internet media. The e-learning system used at the Universitas Advent Indonesia is Moodle. With this Moodle students can upload assignments and download lecture material provided by the lecturer. Whereas for lecturers can upload lecture material and download assignments that have been collected by the students. The purpose of this study are (1) To find out whether the entire menu in the Moodle has been used optimally or not, (2) to find out how the perception of benefits and ease of acceptance of users of the Moodle of the Adventist University of Indonesia. While the results of this study are (1) The acceptance of the Moodle at the Faculty of Information Technology Universitas Advent Indonesia was declared good, (2) the overall use of the menu in Moodle is not optimal yet, and (3) the perception of benefits and easiness influences user acceptance of Moodle.
\end{abstract}

\section{Pendahuluan}

Pendidikan merupakan proses yang dilakukan untuk mengembangkan potensi yang dimiliki seseorang, baik secara formal (lembaga pendidikan) ataupun dari lingkungan dimana kita berada (di luar lembaga pendidikan). Dalam pendidikan yang diikuti maka sarana dan prasarana pembelajaran menjadi satu hal yang dibutuhkan baik bagi pelajar maupun pengajar. E-learning System merupakan salah satu sarana yang banyak digunakan sekarang ini dalam proses belajar dan mengajar. Dengan semakin berkembangnya teknologi internet, maka E-learning System sudah menjadi sarana pembelajaran yang digunakan di hampir semua lembaga pendidikan. Tujuan dari dikembangkannya E-learning System adalah sebagai sarana untuk mendukung proses belajar mengajar dan meningkatkan kualitas layanan kepada peserta didik.

Universitas Advent Indonesia merupakan salah satu lembaga pendidikan yang menggunakan $E$ learning System sebagai sarana pendukung dalam proses belajar dan mengajar. Adapun E-learning System yang digunakan adalah Moodle. Dengan Moodle maka para mahasiswa dapat mengunggah tugas dan 
mengunduh materi perkuliahan yang sudah diberikan oleh dosen. Mahasiswa juga dapat berinteraksi dengan dosen melalui fasilitas chat. Sedangkan bagi dosen dapat mengunggah materi perkuliahan, memberikan ujian secara online, mengunduh tugas dari para mahasiswa dan berinteraksi melalui fasilitas chat. Dengan adanya Moodle ini, proses belajar dan mengajar di Universitas Advent Indonesia khususnya pada Fakultas Teknologi Informasi menjadi lebih bervariasi.

\section{Landasan Teori}

\section{Konsep Dasar Electronic Learning (E-Learning)}

Kharismaputra. A. P (2013:46) mengatakan E-Learning adalah sistem pendidikan yang menggunakan aplikasi elektronik untuk mendukung belajar mengajar dengan media internet, jaringan komputer, maupun komputer standalone.

Allan J. Henderson dalam Siahaan (sebagaimana dikutip pada jurnal Miyono. N, 2013, hlm. 41) mengemukakan bahwa e-learning adalah pembelajaran jarak jauh yang menggunakan teknologi komputer atau yang biasanya disebut internet.

\section{Komponen atau elemen E-Learning}

Menurut Gottschalk (sebagaimana dikutip pada jurnal Intan. M dan Loenard, 2013, hlm. 281), komponen-komponen utama dalam E-learning terdiri dari:

1. Pelajar. Memenuhi kebutuhan pelajar adalah dasar dari setiap E-learning yang efektif.

2. Fakultas. Keberhasilan E-learning tergantung pada fakultas. Peran instruktur dalam E-learning adalah:

a. memahami karakteristik dan kebutuhan pelajar tanpa adanya kontak langsung,

b. mengaplikasikan metode pengajaran yang sesuai dengan harapan belajar,

c. mengembangkan teknologi penyampaian, sementara tetap memfokuskan pada perannya sebagai pengajar

d. berfungsi secara efektif sebagai fasilitator yang mahir.

3. Fasilitator. Seorang fasilitator harus mengerti kebutuhan pelajar dan harapan instruktur. Yang terpenting, fasilitator harus bersedia untuk mengikuti arahan pengajar.

4. Staf pendukung. Staf pendukung memastikan detail-detail yang diperlukan bagi keberhasilan program digunakan secara efektif.

5. Administrator. Administrator berfungsi sebagai pembuat kesepakatan, pembuat keputusan dan penengah.

\section{Karakteristik E-Learning}

Menurut N.E. Ibezim (sebagimana dikutip pada jurnal Sandy Kosasi, 2015, hlm. 84) pada dasarnya bahwa E-Learning memiliki karakteristik yang penting sebagai berikut :

1. Memanfaatkan jasa teknologi internet; di mana guru dan siswa, siswa dan sesama siswa atau guru dan sesama guru dapat berkomunikasi dengan relatif mudah tanpa batasan hal protokoler.

2. Memanfaatkan keunggulan komputer (digital media dan computer network).

3. Menggunakan bahan ajar bersifat mandiri (seft learnign materials) dan dapat diakses oleh guru dan siswa kapan dan di mana saja bila yang bersangkutan memerlukannya.

4. Senantiasa dapat menampilkan jadwal pelajaran, kurikulum, kemajuan belajar dan hal-hal yang berkaitan dengan administrasi pendidikan perserta didik/siswa.

\section{Manfaat E-Learning}

Berdasarkan pengertian dari pada e-learning maka manfaat dari sistem tersebut diantaranya sebagai berikut:

1. Sebagai media pembelajaran yang mendukung dalam proses belajar mengajar.

2. Kegiatan pembelajaran menjadi lebih efektif. Sebab dengan e-learning terbuka peluang yang lebih luas bagi pelajar (peserta didik) untuk berinteraksi dengan guru maupun dengan teman.

3. Pelajar (peserta didik) dapat belajar meskipun tidak hadir secara fisik di dalam kelas.

4. Pelajar dapat mengulang bahan ajaran setiap saat dan di mana saja. 
Menurut A. W. Bates dan K. Wulf (sebagaimana dikutip pada jurnal Tri Rizqi Ariantoro, 2015, hlm. 58) manfaat pembelajaran E-learning terdiri dari empat hal, yaitu:

1. Meningkatkan kadar interaksi pembelajaran antara peserta didik dengan guru atau instruktur (enhance interactivity).

2. Memungkinkan terjadinya interaksi pembelajaran dari mana dan kapan saja (time and place flexibility).

3. Menjangkau peserta didik dalam cakupan yang luas.

4. Mempermudah penyempurnaan dan penyimpanan materi pembelajaran (easy updating of content as well as archivable capabilities).

\section{Keuntungan dan kekurangan E-learning}

Menurut Setyoningsih (2015:52-53) E-learning memiliki keuntungan diantaranya sebagai berikut:

1. Pembelajar dapat memperoleh bahan belajar atau materi serta soal-soal yang harus diselesaikan.

2. Pembelajar dapat mengakses dan mengetahui informasi hasil pekerjaan atau nilai yang diperoleh dari setiap tes yang diselsesaikan.

3. Pembelajar dapat belajar dari komputer pribadi dengan memanfaatkan koneksi jaringan lokal ataupun jaringan internet.

4. Pembelajar dapat menggunakan media CD/DVD yang telah disisipkan.

5. Pembelajar bisa mengatur sendiri waktu belajar, dan tempat dari mana ia mengakses pelajaran.

6. Jumlah pembelajaran yang bisa ikut berpartisipasi dan berinteraksi dalam kegiatan pembelajaran tidak terbatas dan kapasitas kelas.

7. Pembelajar dapat melakukan interaksi secara berkelompok melaui group yang dapat dibuat sendiri oleh para pembelajar berdasarkan tema atau materi pelajaran.

8. Materi pelajaran dapat diketengahkan dengan kualitas yang lebih standar dibandingkan kelas konvensional yang tergantung pada kondisi dari pengajar.

Adapun kekurangan yang ada pada e-learning sebagai berikut:

1. Kurangnya interaksi antara guru dan siswa atau bahkan antar siswa itu sendiri.

2. Kecenderungan mengabaikan aspek akademik atau aspek sosial dan sebaliknya mendorong tumbuhnya aspek bisnis/komersial.

3. Proses belajar dan mengajar cenderung ke arah pelatihan daripada pendidikan.

4. Berubahnya peran guru dari yang semula menguasai teknik pembelajaran konvensional, kini juga dituntut mengetahui teknik pembelajaran yang menggunakna ICT.

5. Siswa yang tidak mempunyai motivasi belajar yang tinggi cenderung gagal.

6. Tidak semua tempat tersedia fasilitas internet.

7. Kurangnya tenaga yang mengetahui dan memiliki keterampilan internet.

\section{Konsep dasar Technology Acceptance Model ( TAM ) \\ Pengertian TAM}

Oktofiyani, dkk (2016:47) berpendapat bahwa model penerimaan teknologi TAM (Technology Acceptance Model) merupakan suatu model penerimaan sistem teknologi informasi yang akan digunakan oleh pemakai.

Paviou (sebagaimana dikutip pada jurnal Firdaus, A, 2012, hlm.32) berpendapat bahwa TAM digunakan sebagi dasar dari berbagai studi sistem informasi teknologi dengan menggunakan dua variabel utama untuk penerimaan teknologi yaitu: persepsi kemudahan penggunaan (Perceived ease of use), dan persepsi manfaat yang dirasakan (Perceived usefulness).

Kharismaputra A.P (2013:46) mengatakan TAM dikembangkan oleh Davis pada tahun 1989 berdasar pada Theory of Reasoned Action (TRA) yang mendasarkan pada psikologi sosial. Sasaran dari TAM adalah untuk menyediakan sebuah penjelasan dari faktor-faktor penentu penerimaan komputer yang umum, dan berfokus pada sikap terhadap pemakain teknologi informasi oleh pemakai dengan mengembangkannya berdasarkan persepsi manfaat dan kemudahan dalam pemakaian teknologi informasi. 


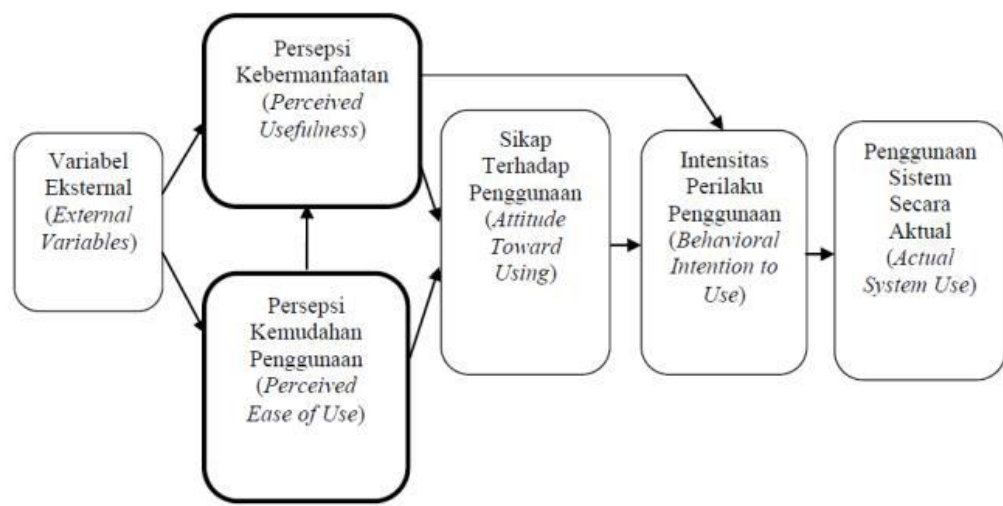

Gambar 2. 1 Technology Acceptance Model

Sumber : Endang Fatmawati (2015:9)

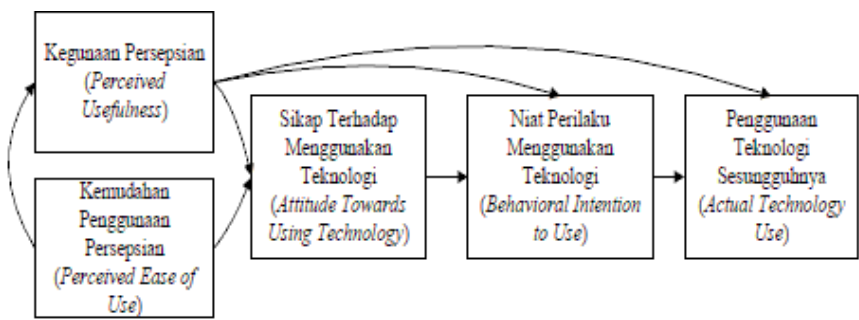

Gambar 2. 2 Techonology Acceptance Model (TAM) yang spesifik menyebut perilaku sebagi penggunaan teknologi

Sumber : Dalimunthe, N., \& Wibisono, H. (2014)

\section{Konstruksi-konstruksi di TAM}

Technology Acceptance Model (TAM) yang pertama yang belum dimodifikasi menggunakan lima konstruks utama. Kelima konstruks ini adalah sebagai berikut:

1. Perceived Ease Of Use

Persepsi kemudahan didefinisikan sebagai sejauh mana seseorang percaya bahwa menggunakan teknologi akan bebas dari usaha.

2. Perceived Usefulness

Persepsi kebermanfaatan didefinisikan sebagai sejauh mana seseorang percaya bahwa menggunakan suatu teknologi akan meningkatkan kinerja.

3. Attitude Towards Using Technology

Sikap terhadap pengguna teknologi didefinisikan sebagai evaluasi pemakai tentang ketertarikannya dalam menggunakan teknologi.

4. Behavioral Intention

Minat Perilaku didefinisikan sebagai minat (keinginan) seseorang untuk melakukan perilaku tertentu. Dapat dikatakan kecenderungan perilaku untuk tetap menggunakan suatu teknologi.

5. Actual Use

Pengguna teknologi sesungguhnya dapat diukur melalui kepuasan pengguna serta jumlah waktu yang digunakan untuk berinteraksi dengan teknologi atau frekuensi pengguna teknologi tersebut.

\section{Tujuan TAM}

Davis (sebagaimana dikutip dalam jurnal Firdaus.A, 2012, hlm. 32) mengatakan tujuan inti dari TAM adalah untuk menyediakan sebuah gambaran yang mendasari pengaruh faktor-faktor eksternal tehadap kepercayaan (belief) internal, sikap dan tujuan. 
Davis mengatakan dalam Kharismaputra. A. P (2013:46) bahwa tujuan utama dari TAM adalah untuk menjelaskan faktor yang mempengaruhi dalam penerimaan Teknologi Informasi dengan jangkauan luas dari teknologi informasi dan populasi dari pengguna.

\section{Metodologi Penelitian \\ Sistem E-learning UNAI}

E-learning yang digunakan pada UNAI adalah moodle. E-learning Moodle yang ada sejak tahun 2007 pada UNAI disediakan untuk semua fakultas yang ada diantaranya yaitu: Fakultas Teknologi Informasi, Fakultas Ekonomi, Fakultas MIPA, Fakultas Pendidikan, Fakultas Filsafat, dan Fakultas Keperawatan. Namun fakultas yang aktif menggunakan adalah fakultas Teknologi Informasi.

\section{Sampel dan Populasi}

Populasi penelitian ini adalah semua mahasiswa Fakultas Teknologi Informasi Universitas Advent Indonesia Bandung mulai tingkat pertama hingga tingkat akhir. Sedangkan sampel pada penelitian ini menggunakan teknik sampling probability dengan proportionate statified random sampling dimana perhitungan ini menurut Sugiyono (2017:82) digunakan bila populasi mempunyai anggota/unsur yang tidak homogen dan berstata secara proporsional. Pada pengambilan sampel menggunakan peluang kesalahan (taraf kesalahan) $10 \%$ karena berdasarkan Sugiyono (2017:86) makin kecil jumlah sampel menjauhi populasi, maka makin besar peluang kesalahan generalisasi (diberlakukan umum).

Sampel dengan cara pengukuran menggunakan teknik slovin (Sujarweni. V. Wiratna, 2014:66).

$$
n=\frac{N}{1+\left(N \times e^{2}\right)}
$$

Dimana: $\mathrm{n}=$ Ukuran sampel

$\mathrm{N}=$ Populasi

e = Prosentasi kelonggaran ketidakterikatan karena kesalahan pengambilan sampel yang masih diinginkan. Sehingga didapat sampel sebesar 64 orang.

\section{Tahap Penelitian}

Adapun tahapan penelitian yang digunakan dalam penelitian ini sebagai berikut:

1. Merumuskan dan mengidentifikasi masalah.

2. Menentukan teknik dan alat untuk pengumpulan data

3. Pengumpulkan data.

4. Penganalisaan data dan pembahasan.

5. Kesimpulan dan saran.

\section{Instrumen Penelitian \\ Variabel penelitian}

Variabel bebas (independen) dimana variabel tersebut adalah persepsi kebermanfaatan (perceived usefulness) dan persepsi kemudahan penggunaan ( perceived ease of use) E- learning System pada Fakultas Teknologi Informasi. Variabel terikat (dependen) dimana variabel tersebut adalah sikap terhadap pengguna teknologi (attitude towards using technology) dalam penerimaan E- learning System.

\begin{tabular}{|l|l|l|}
\hline Variabel & Indikator & Kode kuesioner \\
\hline 1. Persepsi kebermanfaatan & a. Mempercepat pekerjaan & Q1 \\
(perceived usefulness) & b. Meningkatkan kinerja & Q2 \\
2. Persepsi kemudahan & c. Meningkatkan produktivitas & Q3 \\
penggunaan (perceived ease of & d. Efektivitas & Q4 \\
use) & e. Mempermudah pekerjaan & Q5 \\
3. Sikap terhadap pengguna & f. Bermanfaat & Q6 \\
teknologi (attitude towards & a. Mudah dipelajari & Q7 \\
\hline
\end{tabular}


b. Jelas dan mudah dipahami

c. Fleksibel

d. Mudah digunakan.

a. Keyakinan

b. Pengalaman menggunakan
Q8

Q9

Q10

Q11

\section{Analisa Data}

Analisa Deskriptif

Menggunakan analisa deskriptif dengan perhitungan dasar :

Panjang interval kelas (i) = Range/ Jumlah kelas

Dengan perhitungan range $=$ data maksimum - data minimum

\section{Analisa Koefisien Korelasi}

Menggunakan korelasi product moment dengan rumus menurut Jonathan Sarwono, dkk (2017:18) tersebut sebagai berikut:

$$
r=\frac{n \sum X Y-\left(\sum X\right)\left(\sum Y\right)}{\sqrt{\left.\left[n \sum X^{2}\right)-\left(\sum X\right)^{2}\right]\left[n \sum Y^{2}-\left(\sum Y\right)^{2}\right]}}
$$

keterangan:

$r \quad=$ Kofisien Korelasi

$\mathrm{n} \quad=$ jumlah responden

$\Sigma \mathrm{X}=$ jumlah skor variabel $\mathrm{x}$

$\Sigma Y=$ jumlah skor variabel $y$

\section{Analisa Koefisien determinasi} berikut:

Rumus koefisien determinasi menurut Jonathan Sarwono (2017:28) dapat dilihat pada formulasi

$$
K D=(r)^{2} \times 100 \%
$$

keterangan:

$\mathrm{KD}=$ kofisien determinasi

$r=$ korelasi

\section{Uji F}

Melakukan uji F menurut Siregar, M (2013:380) dengan tahap-tahap sebagai berikut:

1. Membuat hipotesis dalam uraian kalimat.

2. Menentukan resiko kesalahan

3. Kriteria pengujian signigikansi

4. Menentukan nilai Fhitung dan Ftabel

5. Membandingkan nilai $F_{\text {hitung }}$ dan $F_{\text {tabel }}$

6. Membuat keputusan apakah $\mathrm{Ha}$ dan $\mathrm{Ho}$ yang diterima.

\section{Uji T (signifikan)} berikut:

Uji t (signifikan) korelasi product moment menurut Jonathan Sarwono,dkk (2017:19) sebagai 
Keterangan:

$$
t_{\text {hitung }}=\frac{r_{x y} \sqrt{(n-2)}}{\sqrt{\left(1-r_{x y^{2}}\right)}}
$$

$r=$ nilai koefisien korelasi

$\mathrm{n}=$ jumlah sampel

Langkah-langkah uji t menurut Siregar, M (2013:382) sebagai berikut: Pengujian koefisien regresi variabel $\mathrm{X} 1, \mathrm{X} 2$

1. Membuat hipotesis dalam uraian kalimat.

2. Menentukan resiko kesalahan $\propto$ (taraf signifikan).

3. Kriteria pengujian:

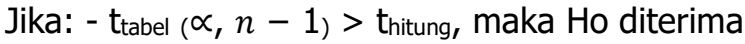

Jika: ttabel $(\propto, n-1)<$ thitung, maka Ho ditolak.

4. Menghitung thitung dan tabel.

5. Membandingkan thitung dan tabel.

6. Mengambil keputusan.

\section{Analisa Regresi linier ganda}

Dengan persamaan menurut Widiyanto, M. A (2014:271) sebagai berikut:

$$
\hat{Y}=a+b_{1} X_{1}+b_{2} X_{2}+b_{3} X_{3}+\ldots . .+b_{k} X_{k}
$$

Keterangan:

$\hat{Y}=$ menyatakan variabel dependen (kriterium/terikat)

$\mathrm{X}_{1}, \mathrm{X}_{2}, \mathrm{X}_{3}, \ldots . \mathrm{X}_{\mathrm{k}}=$ masing-masing menyatakan variabel independen (prediktor/bebas)

$a, b_{1}, b_{2}, b_{3}, \ldots . . b_{k}=$ masing-masing menyatakan taksiran dari parameter regresi linier ganda.

Untuk analisis korelasi ganda dengan dua variabel perdiktor atau independen, bentuk persamaan regresinya adalah sebagai berikut:

$$
\hat{Y}=a+b_{1} X_{1}+b_{2} X_{2}
$$

Menurut Sireger Syofian (2013:406) langkah-langkah untuk membuat persamaan linier ganda sebagai berikut:

1. Membuat tabel penolong

2. Menerapkan motode skor deviasi

3. Mencari nilai konstanta-konstanta

4. Menentukan persamaan regresi dengan dua variabel bebas

$$
\hat{Y}=a+b_{1} X_{1}+b_{2} X_{2}
$$

5. Mencari korelasi berganda

$$
R_{X 1 . X 2 . Y}=\sqrt{\frac{b_{1} \cdot \sum x_{1} y+b_{2} \cdot \sum x_{2} y}{\sum y^{2}}}
$$

6. Mencari koefisien determinasi

$$
K P=\left(R X_{1} X_{2} Y\right)^{2} \times 100 \%
$$




\section{Uji hipotesis}

Hipotesis X1

Ho: persepsi kebermanfaatan (perceived usefulness) tidak berpengaruh signifikan terhadap sikap penggunaan teknologi dalam penerimaan E-learning.

Ha: persepsi kebermanfaatan (perceived usefulness) berpengaruh signifikan terhadap sikap penggunaan teknologi dalam penerimaan E-learning.

\section{Hipotesis X2}

Ho: persepsi kemudahan penggunaan (perceived ease of use) tidak berpengaruh signifikan terhadap sikap pengguna teknologi dalam penerimaan E-learning.

Ha: persepsi kemudahan penggunaan (perceived ease of use) berpengaruh signifikan terhadap sikap pengguna teknologi dalam penerimaan E-learning.

\section{Hipotesis $Y$}

Ho: persepsi kebermanfaatan (perceived usefulness) dan persepsi kemudahan penggunaan (perceived ease of use) tidak berpengaruh signifikan terhadap sikap terhadap pengguna teknologi dalam penerimaan E-learning.

Ha: persepsi kebermanfaatan (perceived usefulness) dan persepsi kemudahan penggunaan (perceived ease of use) berpengaruh signifikan terhadap sikap terhadap pengguna teknologi dalam penerimaan E-learning.

\section{Hasil Analisa}

1. Uji validitas pada penelitian ini menyatakan bahwa setiap butir pertanyaan pada koesioner adalah valid karena nilai t hitung $>$ t tabel pada nilai signifikan $5 \%$ dengan uji dua pihak dengan derajat kebebasan ( $\mathrm{dk}=20-2=18)$, dan uji reabilitas ada penelitian ini mengatakan bahwa setiap butiran pertanyaan memiliki reabilitas tinggi yaitu lebih besar dari 0,7 diketahui melalui hasil pengolahan reabilitas Cronbach's Alpha.

2. Hasil regresi berganda pada penelitian ini menyatakan bahwa persepsi kebermanfaatan dan kemudahan memiliki pengaruh yang positif terhadap sikap penggunaan teknologi. Dikatakan juga bahwa walaupun tanpa persepsi kebermanfaatan (perceived usefulness) dan kemudahan penggunaan (perceived ease of use) terhadap nilai sikap dalam penggunaan dalam penerimaan $E$ learning System tetap ada dan positif.

3. Nilai daripada koefisien korelasi $(R)$ menyatakan bahwa korelasi tersebut berdasarkan perhitungan memiliki hubungan yang sangat rendah sesuai dengan kriteria interval koefisien (Riduwan, M.B.A. (2014:136) yaitu sebesar 0,142 atau 37, 7 \%. Disimpulkan bahwa kenaikan satu satuan yang terjadi pada X1 dan X2 memiliki pengaruh yang rendah terhadap kenaikan Y.

4. Hasil dari perhitungan pada uji t diperoleh nilai t hitung untuk $X 1$ sebesar 0,692 . Nilai tersebut bahwa t hitung $(0.692)<\mathrm{t}$ tabel (2.298078) maka H0 diterima dan Ha ditolak yang berarti secara parsial persepsi kebermanfaatan (perceived usefulness) (X1) tidak berpengaruh pada sikap terhadap penggunaan teknologi (attitude towards using technology) $(Y$ ) dalam penerimaan $E$ learning System. Analisa pengaruh X1 terhadap Y yang dinilai pengguna dalam penerimaan $E$ learning System menyimpulkan bahwa variabel $\mathrm{X} 1$ secara parsial tidak berpengaruh signifikan terhadap Y.

5. Sedangkan nilai t hitung untuk $X 2$ sebesar 0,692 . Nilai tersebut bahwa t hitung (2.562) $>\mathrm{t}$ tabel (2.298078) maka H0 ditolak dan Ha diterima yang berarti secara parsial persepsi kemudahan (X2) berpengaruh pada sikap terhadap penggunaan teknologi (attitude towards using technology) $(\mathrm{Y}$ ) dalam penerimaan E-learning System. Analisa pengaruh $\mathrm{X} 2$ terhadap $\mathrm{Y}$ yang dinilai pengguna dalam penerimaan E-learning System menyimpulkan bahwa variabel X2 secara parsial berpengaruh signifikan terhadap $\mathrm{Y}$.

6. Hasil uji f yang diperoleh dari tabel uji $f$ yaitu sebesar 5,066 . Nilai signifikan sebesar 0,009 dimana nilai signifikansi < dari nilai - yaitu 0,05. Ho ditolak dan Ha diterima yang memiliki arti bahwa analisa pengaruh $\mathrm{X} 1$ dan $\mathrm{X} 2$ tehadap $\mathrm{Y}$ yang dinilai pengguna dalam penerimaan E-learning System, secara bersama-sama berpengaruh terhadap penerimaan E-learning System. 
7. Variabel $X 2$ memiliki pengaruh kuat terhadap $Y$ berdasarkan pada tabel uji t. Nilai tersebut dapat dilihat pada nilai beta variabel $X 1$ adalah 0,102 dan nilai beta variabel $X 20,417$. Dapat disimpulkan bahwa nilai beta $\mathrm{X} 1<$ dari nilai beta $\mathrm{X} 2$.

\section{Kesimpulan dan Saran \\ KESIMPULAN}

Kesimpulan yang didapat dalam penelitian ini sebagai berikut:

1. Tingkat interval persepsi sikap terhadap penggunaan menyatakan berada pada rentang 10881344 dengan kategori baik, sehingga tanggapan responden terhadap penerimaan E-learning System pada Fakultas Teknologi Informasi Universitas Advent Indonesia dinyatakan baik.

2. Berdasarkan akumulasi tanggapan responden penggunaan keseluruhan menu dalam E-learning System pada Moodle UNAI belum maksimal karena masih berada pada tingkat interval baik berdasarkan perhitungan tingkat interval persepsi kebermanfaatan dan persepsi kemudahan.

3. Persepsi kebermanfaatan dan kemudahan secara bersama-sama berpengaruh terhadap sikap dalam penggunaan teknologi pada E-learning System. Namun persepsi kebermanfaatan secara parsial tidak berpengaruh secara signifikan terhadap sikap dalam penerimaan teknologi pada $E$ learning System, sedangkan persepsi kemudahan secara parsial berpengaruh signifikan terhadap sikap dalam penerimaan teknologi pada E-learning System.

\section{SARAN}

Adapun saran-saran yang diusulkan oleh peneliti pada penelitian ini sebagai berikut:

1. Mensosialisasikan penggunaan menu-menu yang lain dari Moodle agar penggunaan Moodle dapat lebih optimal.

2. Lebih mensosialisasikan penggunaan Moodle kepada fakultas lain agar Moodle dapat digunakan tidak hanya oleh Fakultas Teknologi Informasi saja, tetapi dapat digunakan oleh seluruh fakultas yang ada di Universitas Advent Indonesia.

\section{Referensi}

1. Kharismaputra, A. P. (2013). Analisis Penentu Penerimaan Sistem Informasi E-Learning Oleh Siswa Smk Di Surakarta Tahun 2012. Jurnal Pendidikan Bisnis dan Ekonomi (BISE), Vol.1 No.1. Tersedia: https://eprints.uns.ac.id/1153/1/ 2103-4752-1-SM.pdf, diakses 9 November 2017

2. Miyono, N. (2013). Analisis E- Learning Menggunakan Techology Acceptance Modelling (Study Kasus Pada Stmik Provinsi Semarang). Jurnal Transformatika, Volume 11, No.1, 39-50. Tersedia:http://journals.usm.ac.id/index. php/transformatika/article/view/94/92, diakses 18 September 2017

3. Sari, P. (2015). Memotivasi Belajar Dengan Menggunakan E- Learning. Jurnal Ummul Qura Vol VI, No 2. Tersedia: http://ejournal.kopertais4.or.id/ pantura/index.php/qura/article/ view/2048, diakses 5 April 2018.

4. Sampurno, P. J., Maulidiyah, R., \& Puspitaningrum, H. Z. (2013). Implementasi Kurikulum 2013: MOODLE (Modular Object Oriented Dynamic Learning Environment) dalam Pembelajaran Fisika melalui Lembar Kerja Siswa pada Materi Optik di SMA. Jurnal Fisika Indonesia No: 55, Vol XIX, Edisi November 2015 ISSN: 1410-2994. Tersedia: http://pdm-mipa.ugm.ac.id/ojs/index.php/jf i/article/view/1026/1146, diakses 8 April 2018.

5. Mutia, I. (2013). Kajian Penerapan E- Learning Dalam Proses Pembelajaran Di Perguruan Tinggi. Jurnal Faktor Exacta. Tersedia:https://www.google.com/search?client=opera\&q=Mut $\mathrm{ia}+\% 26+$ Leonard. +Kajian+Penerapan+ELearning+Dalam+Proses+Pembelajaran+Di+Perguruan +Tinggi+(2013)\&sourceid=opera\&ie=UTF-8\&oe=UTF-8, diakses 9 April 2018

6. Kosasi, S. (2015). Perancangan E- Learning untuk Meningkatkan Motivasi Belajar Guru dan Siswa. SENAPATI. Tersedia: http://www.jurnal.stmikpontianak.ac.id/file/sandy_kosasisenapati_2015.pdf, diakses 23 April 2018

7. Ariantoro, T. R. (2015). Penerapan model pembelajaran E- Learning untuk meningkatkan hasil belajar mata kuliah komputer mahasiswa program studi kebidanan di STIK Bina Husada Palembang. 
8. Ristiadi, T. (2015). Efektivitas Dan Penerimaan Teknologi E-Learning Edmodo Di Jurusan Multimedia Sekolah Menengah Kejuruan Negeri 1 Klaten. Tersedia: http://eprints.uny.ac.id/33184/1/TITO\%20RISTIADI_11520244022.pdf, diakses 23 April 2018.

9. Setyoningsih. (2015). E-Learning: Pembelajaran Interaktif Berbasis Teknologi Informasi. Elementary Vol.3, No.1.

10. Wicaksono, A. R., Winarno, W. W., \& Sunyoto, A. (2015). Perancangan dan implementasi ELearning pendukung project. Seminar Nasional Teknologi Informasi Dan Komunikasi 2015 (SENTIKA 2015). Tersedia: https://www.academia.edu/11751529/Perancangan_Dan_Impl ementasi_E- Learning_Pendukung_Project_Based_Learning, diakses 9 April 2018

11. Sampurno, P. J., Maulidiyah, R., \& Puspitaningrum, H. Z. (2013). Implementasi Kurikulum 2013: MOODLE (Modular Object Oriented Dynamic Learning Environment) dalam Pembelajaran Fisika melalui Lembar Kerja Siswa pada Materi Optik di SMA. Jurnal Fisika Indonesia No: 55, Vol XIX,Edisi November 2015 ISSN: 1410-2994. Tersedia: http://pdm- mipa.ugm.ac.id/ojs/index.php/jf i/article/view/1026/1146, diakses 8 April 2018.

12. Amiroh (2012). Kupas Tuntas Membangun E-Learning dengan Learning Management System moodle. Sidoarjo: Genta Group Production PT Berkah Mandiri Globalindo. Tersedia: https://books.google.co.id/books?id=iVGLBAAAQBAJ\&printsec=frontcover\&dq=e+learning + syste $\mathrm{m} \& \mathrm{hl}=\mathrm{id} \& \mathrm{sa}=X \&$ redir_e $\mathrm{sc}=\mathrm{y} \# \mathrm{v}=$ onepage\&q=e\%20lear ning\%20system\&f=true, diakses 18 Oktober 2017

13. Oktofiyani, R., Nurmalasari, \& Anggraeni, W. (2016). Penerimaan Sistem E-Learning Menggunakan Technology Acceptance Model (Tam) Study Kasus Siswa/I Kelas X Di Smu Negri 92 Jakarta. Jurnal Pilar Nusa Mandiri Vol.XII, No.1. Tersedia: http://pilar.nusamandiri.ac.id/index.php/pilar/article/view/62/6 0, diakses 19 September 2017

14. Firdaus, A. (2012). Analisa penerimaan penggunaan sistem inforamsi akademik menggunakaN hipotesis Technology Acceptance Model (TAM). Jurnal OC PUS, V ol $4 \mathrm{~N}$ o. 2 . Tersedia: http://eprints.polsri.ac.id/38/1/j urnal\%200CPUS\%20TAM.pdf diakses 25 September 2017

15. Setiawan, E. (2018). Retrieved Mei 4,018, from Kamus Besar Bahasa Indonesia: https://www.kbbi.web.id, diakess 23 April 2018

16. Satya, B., \& Aditya, R. (2013). Analisis Penerimaan (Acceptance) Penerapan Internet Sehat. Jurnal Dasi Vol.14, No.1. Tersedia: http://ojs.amikom.ac.id/index.p hp/dasi/article/view/148, diakses 11 April 2018

17. Sugiyono. (2017). Metode Penelitian Kuantitatif, Kualitataif, dan R\&D. Bandung: Alfabeta, CV.

18. Sujarwani, V. W. (2014). Metodologi Penelitian Lengkap, Praktis, Dan Mudah Dipahami. Yogyakarta: Pustakabarupress.

19. Sarwono, J., \& Salim, H. N. (2017). Prosedur-Prosedur Populer Statistika Untuk Analisis Data Riset Skripsi. Yogyakarta: Penerbit Gava Medika.

20. Siregar, S. (2013). Statistik Parametik untuk Penelitian Kuantitatif: dilengkapi dengan perhitungan manual dan aplikasi SPSS versi 17. Jakarta: Bumi Aksara. Widiyanto, M. A. (2014). Statistik untuk penelitian bidang teologi, pendidikan Agama Kristen, pelayanan gereja. Bandung: kalam hidup. 